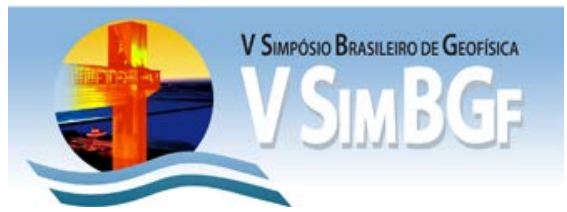

\title{
EMAG2 and a new version of the Magnetic Map of Brazil.
}

Marcos de Barros Munis * ${ }^{1}-$ marcos.munis@cprm.gov.br

José Ribamar Lopes Bezerra ${ }^{2}$, João Batista Freitas de Andrade ${ }^{1}$, Renato Lopes Silveira ${ }^{2}$

${ }^{1}$ CPRM/SGB - Brazilian Geological Survey and ${ }^{2}$ ANP - Petroleum National Agency

Copyright 2012, SBGf - Sociedade Brasileira de Geofísica

Este texto foi preparado para a apresentação no V Simpósio Brasileiro de Geofísica, Salvador, 27 a 29 de novembro de 2012. Seu conteúdo foi revisado pelo Comitê Técnico do V SimBGf, mas não necessariamente representa a opinião da SBGf ou de seus associados. É proibida a reprodução total ou parcial deste material para propósitos comerciais sem prévia autorização da SBGf.

\section{Abstract}

The earth's magnetic field is originated in its nucleus according to the geodynamos theory and propagates throughout the mantle, the crust and far way. Except during the occurrences of magnetic storms, more than $95 \%$ of the measured magnetic signal comes from the core. The specialized exploration geophysicist acting on oil/gas or mineral industries has it focus in the interactions of this main field, and the secondary one, induced by the first, on magnetic rocks of upper crust, since de lower crust is hotter than the Curie point. The knowledge of the magnetic signatures of entire countries or even, continents, is a powerful tool to better understand the geological behavior of the upper part of the crust, in which, sedimentary basins, igneous intrusions or metalogenetic provinces are developed. This paper deals with EMAG2 data compared with aeromagnetic data from Arco Purus region in Amazonas State, and does some considerations on a new version of the Brazil Magnetometric Map.

\section{Introduction}

A 2-arc-minute resolution Earth Magnetic Anomaly Grid (EMAG-2) compiled from satellite, airborne or marine magnetic measurements (Maus et al., 2009) is available since 2009 from the NOAA - NGDC internet page. The survey covers nearly all the earth surface and the download of these data is free. One characteristic of the potential methods is that the amplitude of the anomalies decays very fast with the increasing of the source-sensor distance. The distance of the magnetic satellites from the geoid is about $350 \mathrm{~km}$, a distance too great for exploration purposes, and very low for others satellites applications. These low altitude satellites have short life due the friction with the atmosphere. Although the facilities to obtain these satellite data, the resolution of the signal is much weaker than that got from air surveys, but continue development of technical acquisition and processing are been made. In 1958, the Sputnik 3 (USSR) with a fluxgate magnetometer collected magnetic data from the space, with accuracies of about $100 \mathrm{nT}$. The first satellite used to regular magnetic acquisition was the MAGSAT launched in 1979 and burned in 1980 during the reentry in the atmosphere. Followed by OERSTED (1999) and CHAMP (Challenging Mini-satellite
Payload, 2000), these satellites are the main source of EMAG2 data. Satellites and airborne surveys have different goals and despite the limitations, the contribution of the satellites has been encouraging in the understanding of the geological behavior of the crust (Fairhead, 2003).

\section{EMAG2 x Airborne magnetic data}

EMAG2 data are delivered in grid format (XYZ ASCII file) and figure 1 shows the data corresponding to the SA.19, SA.20, SA. 21 , SB. 19 , SB. 20 and SB. 21 from latitudes $0^{\circ}$ to $-8^{\circ}$ and longitudes $-72^{\circ}$ to $-54^{\circ}$.

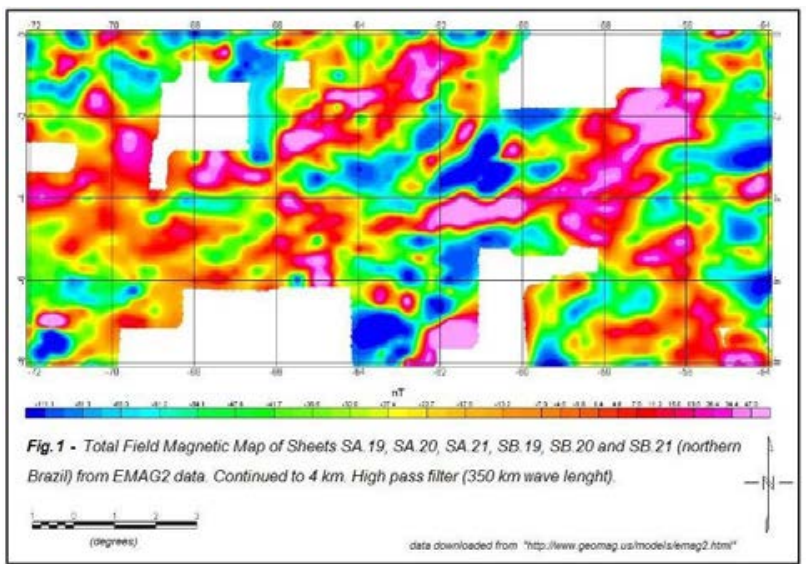

Munis (2009) did an extensive interpretation on old magnetic surveys supported by gravity, seismic and well data, looking for the tectonic behavior of Purus Arch, in Solimões River region, north of Brazil. Four projects were studied: Manaus E, flew in 1957, Manaus W in 1960/61, Carauari in 1981/82 and Coari in 1984. The first two was flown without digital record data and was recovered from contour maps of total magnetic field reduced from arbitrary datuns. The others were in digital format and IGRF reduced, but noisy, especially in flight line direction demanded a rigorous micro leveling treatment. Results shows that, Purus Arch is an inverted graben of NeoProterozoic age with N-S direction and 250 to $300 \mathrm{~km}$ wide. It separates Solimões and Amazonas basins since Devonian time. Besides that, the study showed magnetic patterns on Solimões basin due to sills folds and faults which can increase the earning on oil and gas exploration effort, and strong evidences of neotectonic activities controlling the actual Solimões river course (Munis et al, 
2010). Figure 2 presents the magnetic total field map upward to $1 \mathrm{~km}$ altitude at the same scale of figure 1.

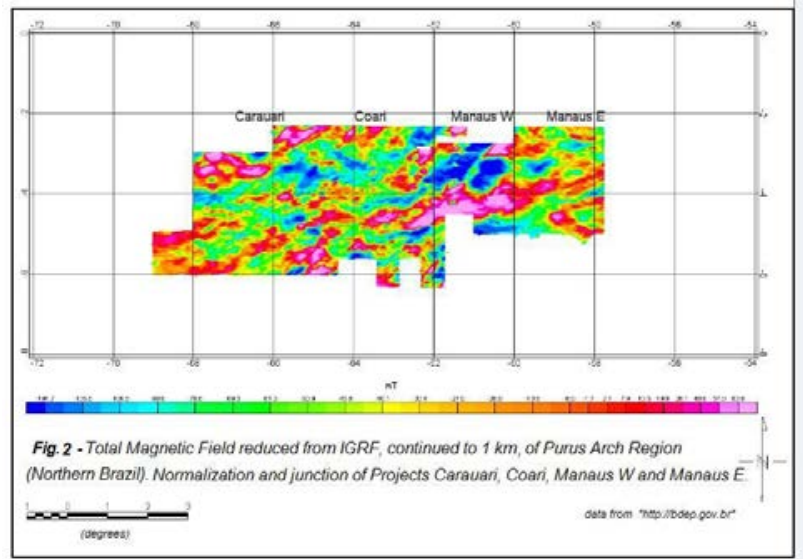

Figure 3 is a composition of figures 1 and 2, but this last one upward to $4 \mathrm{~km}$ to compare with EMAG2 data. We can see clearly very different contents of frequencies and amplitudes. This means that we don't know how types or parameters were used to get this last one grid.

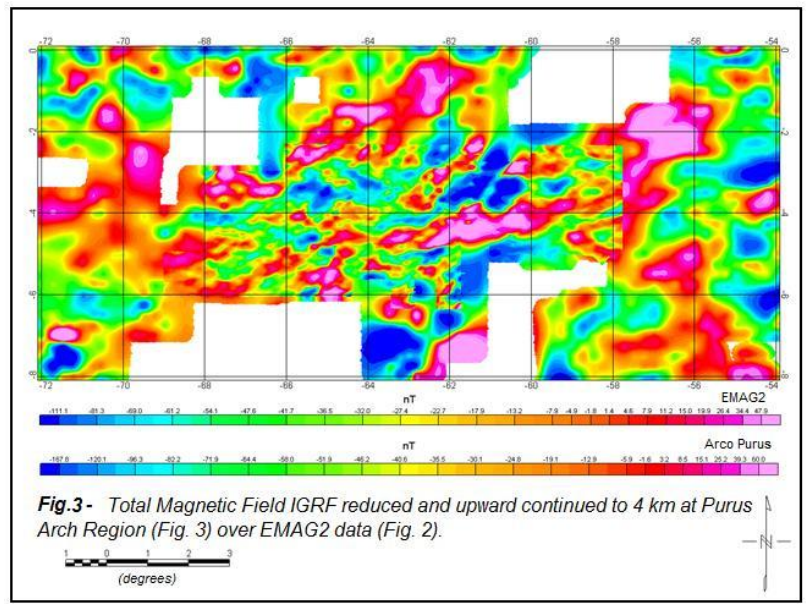

Figures 4 and 5 show the radially averaged power spectrum of these data. The greater depths of magnetic sources from EMAG2 data in respect to Purus Arch data are highlighted. Note the two color scales on figure 3 due to different range in amplitudes. In both cases, the depths must be subtracted in $4 \mathrm{~km}$, due to previous filtered used. The Nyquist frequency in EMAG2 case is 0.27 corresponding to $3.7 \mathrm{~km}$ wavelength.
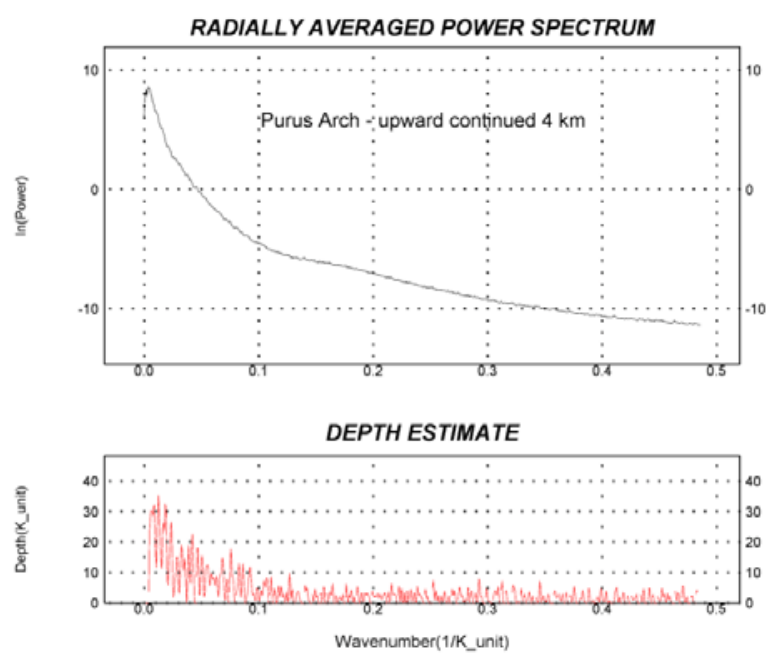

Fig. 4- Radial power spectrum of airtome magnetic data from Punus Arch region upward to $4 \mathrm{~km}$
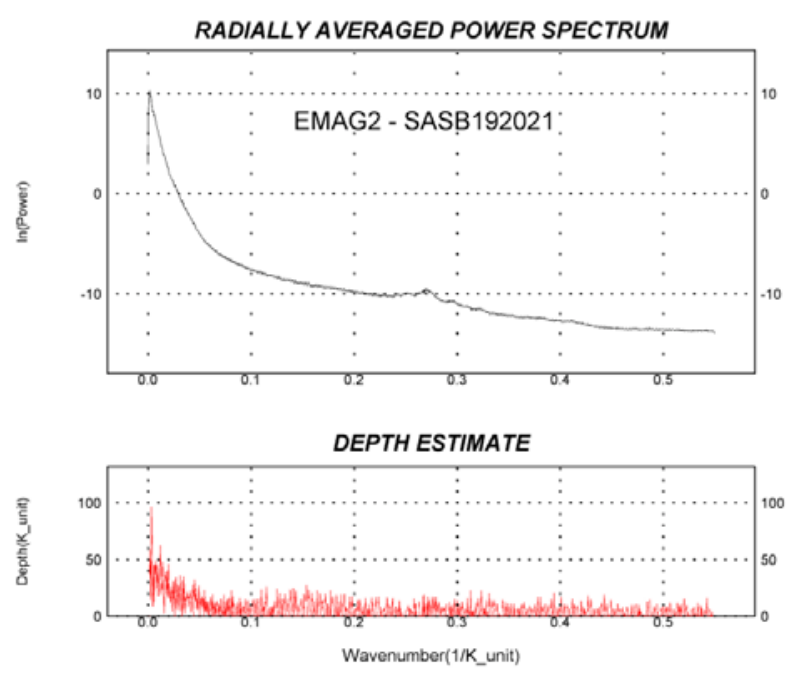

airbome magnetic data from Purus Arch region upward to $4 \mathrm{~km}$ Fig. 5. Radial power spectrum of EMAG2 data trom SA. 19, SA.20, SA.21, SB19, SB20 and SB21 Shoots, continued to $4 \mathrm{~km}$.

\section{Magnetic Map of Brazil}

Brazil is almost covered by magnetic airborne surveys and the data are controlled by two government agencies: The ANP (Petroleum National Agency) and CPRM-SGB (Minerals Resources Research Company - The Brazilian Geological Survey) as showed in figure 6 . The idea to present a regional magnetic map of Brazil was presented in the First International Congress of SBGf held in 1989 at Rio de Janeiro (Ferreira et al, 1989 and 1989b). 


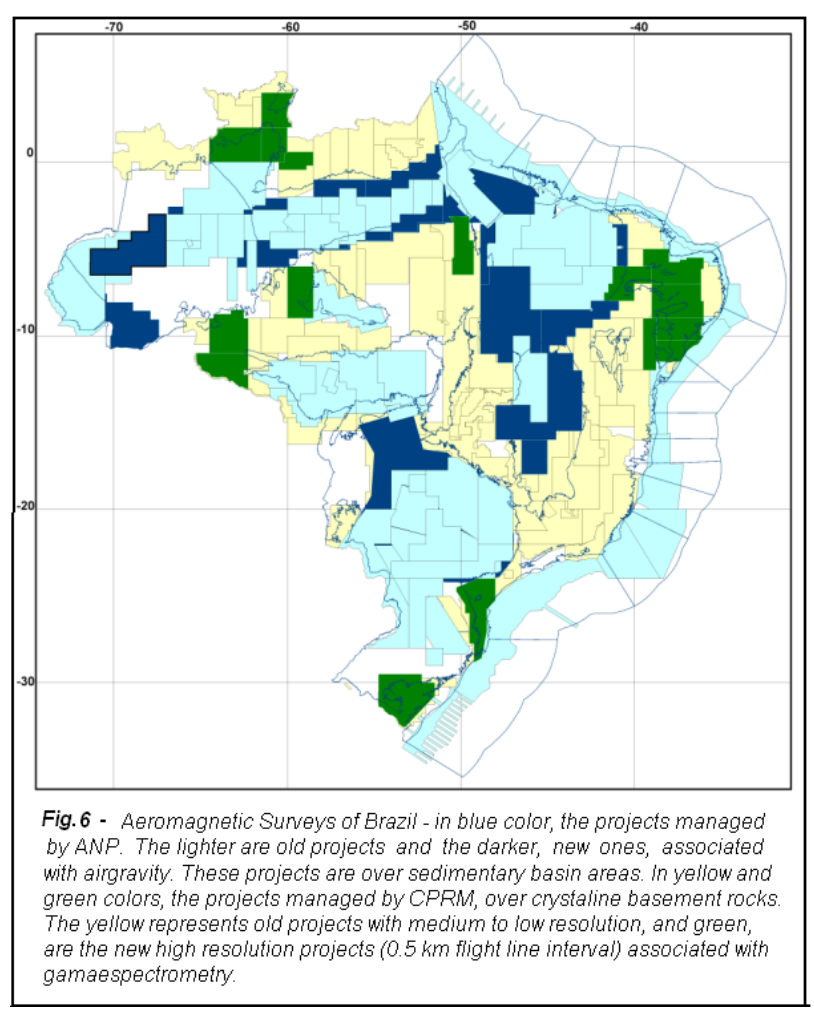

The results were focused on NE region including the continental platform area, with Petrobras data. During the Second International Congress, held at Salvador, Moraes et al, (1991), presented an amplified version including data from Petrobras and CPRM available until then. After that, Getech (University of Leeds) and PGW (Paterson, Grant \& Watson) with CPRM recompile and reprocess the data in the SAMMP (South America Magnetic Map Project). CPRM through DIGEOF (Geophysical Division) did some updates on this map and presented it on some SBGf congress. The last one is the result of cooperation work between ANP and CPRM and was presented in the $12^{\text {th }}$ International Congress of the Brazilian Society held in Rio de Janeiro on August, 2011 and Figure 7 is a reproduction of this map. Countries with continental extension like Australia (Tarlowsky et al., 1997), Canada, United States and Mexico (Bankey et al., 2002) published magnetic regional maps covering the entire countries and providing great service to mineral and petroleum industry. Considering the great collecting of new data acquired, some of them with high resolution accuracy as seen in figure 6 , and the best facilities provided by new processing techniques, a new interpretive challenge is offered to Brazilian geoscientists.

\section{Conclusions}

In the last two decades Brazil by CPRM, ANP and other entities of state government (CODEMIG, CBPM and others) has acquired a vast quantity of new aeromagnetic data, some of them with air-gravity and others with airgamaespectrometry. These data replaces old low resolution projects or partially supply the areas with no previous data. The new agreement between CPRM and ANP to increase knowledge of sedimentary basins and its relations with the cratonic areas including basin analysis, metalogenetic processes, determination of Curie surface and the implications with global tectonics have now a great help with the availability of such data.

\section{Acknowledgments}

We want to thank CPRM and ANP for making possible the publication of this work.

\section{References}

Bankey, V., Cuevas, A., Daniels, D., Finn, C. A., Hernandez, I., 2002, "Digital data grids for the magnetic anomaly map of North America", preliminary report in http://pubs.usg.gov/of/2002/ofr-02-414/

Fairhead, J. D. 2003, "Champ satellite and terrestrial magnetic data", The Leading Edge, August 2003.

Ferreira, F.J.F., Monma, R., Hora, M. P. P. B., Latgé, M. A. L., Munis, M. de B., Moraes, R. A. V., Vasconcellos, R. M., Quintão, S. L. S., Gonzaga, P. M., 1989, "Carta aeromagnética do Brasil a 1:2.500.000 - Plataforma Continental Nordeste", 1st International Congress of SBGf, p. 203, 203, Rio de Janeiro, Brazil.

Ferreira, F.J.F., Monma, R., Hora, M. P. P. B., Latgé, M. A. L., Munis, M. de B., Moraes, R. A. V., Vasconcellos, R. M., Quintão, S. L. S., Gonzaga, P. M., 1989, "Carta aeromagnética do Brasil ao milionésimo", 1st International Congress of SBGf, p. 137, 137, Rio de Janeiro, Brazil.

Maus,S., Barchausen, U., Berkenbosch, H., Bournas,N.,Brozena, J., Childers, V., Dostaler, F. Fairhead, J., Finn, C., Frese, B., Gaina, C., olynsky, S., Kucks, R., Luhr, H., Milligan, P., Mogren, S., Muller, D., Olesen, O., Pilkington, M. Saltus, R., Schrekenberger, B., Thebault, E., Tontini, F., (2009), "EMAG2", Journal of Geophysical Research, XXX, DOI:10.1029.

Moraes, R. A. V., Ferreira, F. J. F., 1991, "Mapa magnético do Brasil na escala 1:5.000.000", in 2nd Internacional Congress of SBGf held in Salvador, Brazil.

Munis, M. de B., 2009, "Caracterização geomagnética do graben Purus e suas implicações na evolução das bacias do Solimões e do Amazonas", tese de doutorado, COPPE-UFRJ.

Munis, M. de B., Landau, L., Coutinho, M. G. da N., 2010, "Controle neotectônico do Rio Solimões detectado em assinaturas magnéticas regionais", 45 Congresso Brasileiro de Geologia, SBG, Belém, PA. 
Tarlowski, C., Gunn, P.J., Mackey, T., 1997

"Enhancements of the magnetic map of Australia", Journal of Geol. and Geophy., 17(2) p.77-82.

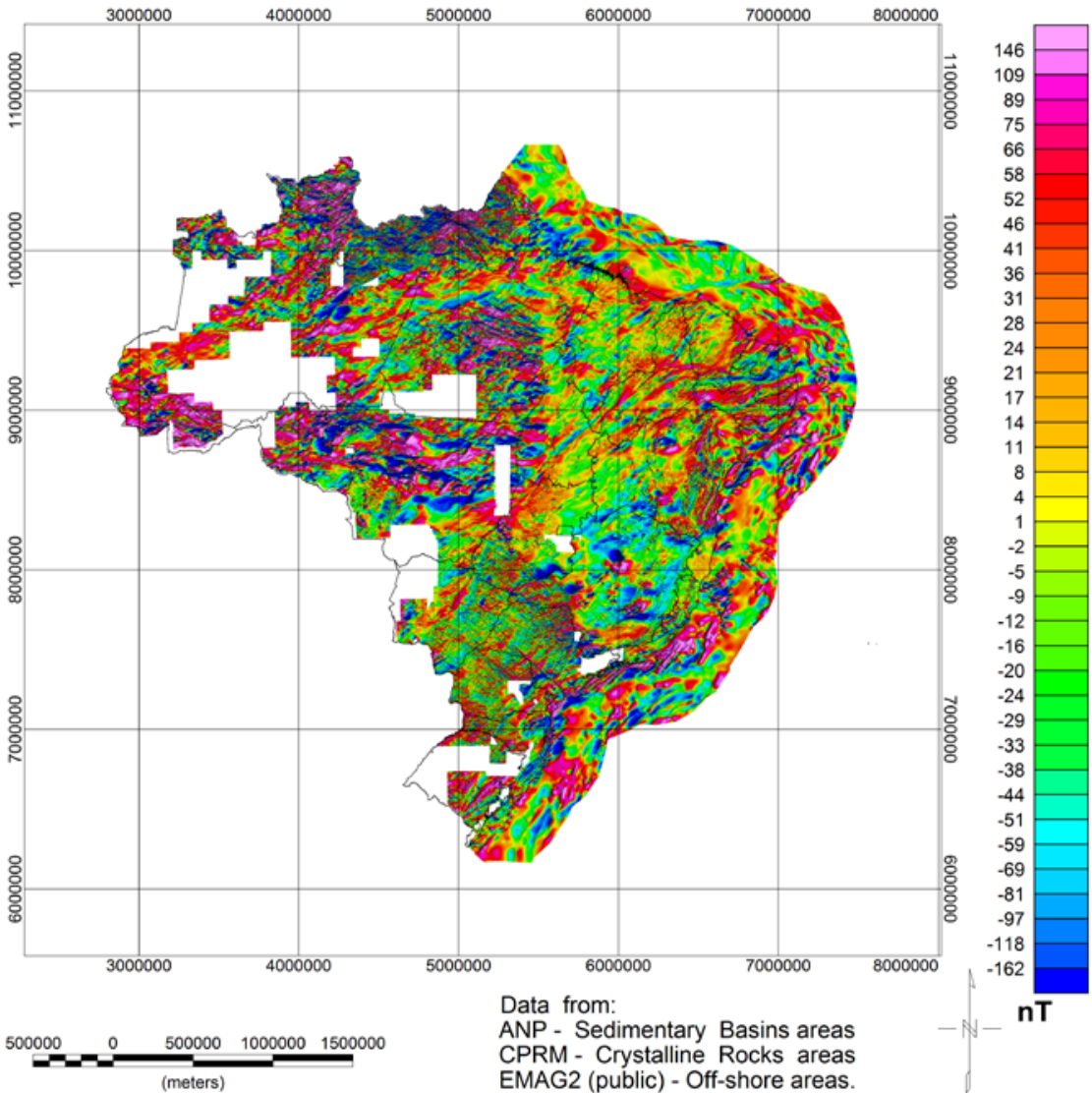

Fig. 7 - Total Intensity Magnetic Map of Brazil. Upwarded to $1 \mathrm{~km}$. Grid cell = $1 \mathrm{~km}$. Updated Dec. 2011. 